\title{
Karakterisasi Fisik Pati Tapioka Modifikasi Gabungan Hidroksipropilasi dengan Fosfat-Ikat Silang
}

\author{
Physical Characteristics of Double Modified Tapioka Starch with \\ Hydroxypropylation and Phosphate Cross-Linked
}

\author{
Didah Nur Faridah $^{1 *}$, Ali Thonthowi ${ }^{2)}$ \\ 1) Departemen Ilmu dan Teknologi Pangan, Fakultas Teknologi Pertanian, Institut Pertanian Bogor, Bogor \\ 2) Program Studi Teknologi Pangan, Departemen Ilmu dan Teknologi Pangan, Fakultas Teknologi Pertanian, \\ Institut Pertanian Bogor, Bogor
}

\begin{abstract}
Native tapioca starch has limited application in food industry due to its physicochemical characteristics that are not suitable for processing conditions, such as unstable at high temperature heating, acidic conditions, stirring, and undergoing syneresis. This deficiency can be overcome by applying a dual modification involving hydroxypropylation and cross-linking with phosphates. In this study, modification was carried out by hydroxypropylation using propylene oxide (8, 10, and 12\%), followed by cross-linking with a combination of sodium tripolyphosphate (STPP) and sodium phosphate (STMP) with a ratio of 2\%: $5 \%$. The modified tapioca starch had water content of 7.82-8.19\% with a pH value of 7.047.26, and phosphorus resiude of $<0.4 \%$. There were no change in starch granules and type of cristalline (A-tyype) of starch modifications. The dual modified starch with the addition of 10\% propylene oxide concentration with a mixture of STMP : STTP ratio (2\%:5\% was selected to have acceptable physicochemical properties. It showed lowered pasting temperature, minimum break down viscosity, increased peak and setback viscosity compared to that of native starch. The modified tapioca starch also showed more heat stable and stirring resistant than that of native tapioca starch.
\end{abstract}

Keywords: crosslinking, double modification, hidroksipropilation, tapioka starch

\begin{abstract}
Abstrak. Pemanfaatan pati tapioka alami terbatas di industri pangan, karena memiliki karakteristik fisikokimia yang kurang sesuai dengan kondisi proses. Oleh karena itu, pati alami biasanya dimodifikasi sesuai dengan kebutuhan proses, seperti tidak tahan pemanasan suhu tinggi, kondisi asam, pengadukan, dan mengalami sineresis. Kekurangan ini dapat diatasi dengan menerapkan modifikasi ganda yang melibatkan proses hidroksipropilasi dan ikat-silang dengan fosfat. Dalam penelitian ini, modifikasi dilakukan dengan hidroksipropilasi menggunakan propilena oksida $(8,10$, dan 12\%), yang dilanjutkan ikat silang dengan kombinasi sodium tripolifosfat (STPP) dan sodium fosfat (STMP) dengan rasio 2\%:5\%. Setelah adanya modifikasi, kadar air pati menurun menjadi 7.82\%-8.19\% dengan nilai pH kisaran 7.04-7.26. Semua perlakuan modifikasi pati menghasilkan kadar fosfor $<0.4 \%$. Tidak ada perubahan bentuk granula pati dan tipe kristalin (tipe A) sebelum dan sesudah modifikasi. Perlakuan terbaik didapatkan pada pati tapioka yang dimodifikasi ganda dengan penambahan konsentrasi propilen oksida sebesar 10\% dengan campuran rasio STMP : STTP (2\%:5\%). Tapioka termodifikasi yang dihasilkan mengalami penurunan suhu awal gelatinisasi dan viskosistas break down, serta peningkatan viskositas puncak dan viskositas setback dibandingkan tapioka kontrol. Pati tapioka termodifikasi juga lebih tahan panas dan lebih stabil oleh proses pengadukan dibandingkan pada tapioka alami.
\end{abstract}

Kata Kunci: hidroksipropilasi, ikat silang, modifikasi ganda, pati tapioka

Aplikasi Praktis. Hasil penelitian ini menghasilkan pati tapioka termodifikasi ganda, yaitu hidrok-
sipropilasi dan ikat silang dengan menggunakan propilena oksida dan campuran STTP dan STMP. Pati
tapioka hasil modifikasi ganda tersebut memiliki sifat tahan panas dan tahan pengadukan sehingga dapat
diaplikasikan sebagai pengental pada produk pangan yang mengalami proses pemanasan.

\section{PENDAHULUAN}

Pati merupakan salah satu komponen ingredien bahan pangan dengan aplikasi industri yang luas. Pati tersusun atas polisakarida dari molekul $\alpha$-D-glukosa. Molekulnya terdiri atas fraksi amilosa linear dan amilo- pektin yang bercabang (Atichokudomchai et al. 2000; Beninca et al. 2008). Kedua molekul tersebut berperan atas sifat fisik dan kimia pada pati yang berpengaruh pada tingkat kelarutan dan pembengkakan granula pati. Pati alami memiliki aplikasi industri yang terbatas karena sifatnya yang tidak tahan terhadap panas dan tegangan 
geser, serta cepat mengalami retrodragasi dan sineresis Oleh karena itu, dilakukan berbagai modifikasi pada pati alami untuk mengoreksi satu atau beberapa kekurangan pada sifat fungsional pati agar aplikasinya lebih luas (Neelam et al. 2012).

Teknik modifikasi pada pati dapat dilakukan dengan beberapa metode, salah satunya dengan menerapkan modifikasi ganda menggunakan proses hidroksipropilasi dan ikat silang. Modifikasi ganda hidroksipropilasi dan ikat silang secara signifikan memengaruhi komposisi amilosa dan amilopektin pada pati (Maulani et al. 2013). Modifikasi ganda ini juga mengubah sifat pati alami seperti meningkatkan viskositas puncak, kemampuan mengembang, kejernihan, kelarutan serta dapat menurunkan tingkat sineresis pada pati (Haq et al. 2019).

Modifikasi pati menggunakan proses hidroksipropilasi melibatkan reaksi eterifikasi dengan propilena oksida dalam katalis basa. Hidroksipropil $\left(-\mathrm{OCH}_{2} \mathrm{CH}_{2} \mathrm{CH}_{3}\right)$ dapat mensubstitusi rantai hidroksil pati, sehingga ikatan hidrogen antar dan intra-molekul pati akan melemah. Hal ini dapat menyebabkan rantai pati menjadi lebih fleksibel pada daerah amorfnya (Greenwood et al. 1977). Berdasarkan penelitian yang telah dilakukan oleh Moin et al. (2017) terhadap kestabilan tekstur puding beras pada penyimpanan $4^{\circ} \mathrm{C}$ selama tiga hari menyatakan bahwa penggunaan pati beras termodifikasi hidroksipropilasi terbukti dapat mempertahankan tekstur keras pada pudding serta dapat meningkatkan kejernihan pasta hingga $3.7 \%$ pada penyimpanan hari ke-7. Selain itu, menurut Senanayake et al. (2014), substitusi hidroksipropil secara signifikan dapat meningkatkan kelarutan pati dalam air, meningkatkan stabilitas gel pati, serta menurunkan suhu gelatinisasi pati ubi jalar.

Modifikasi secara ikat-silang dapat mempertahankan ikatan hidrogen pada granula pati dengan ikatan kimia yang berfungsi sebagai jembatan antar molekul pati. Faktor penting yang harus diperhatikan dalam reaksi ikat silang adalah komposisi reagen, konsentrasi, $\mathrm{pH}$, waktu, dan suhu reaksi (Hirsch dan Kokini 2002). Viskositas pada pati akan lebih stabil apabila dalam proses modifikasi ikat silang ditambahkan campuran sodium tripolifosfat (STPP) dan sodium fosfat (STMP) (Lim dan Seib 1993). Penggunaan kedua bahan ini pada modifikasi pati oat terbukti dapat meningkatkan kapasitas pembengkakan granula pati, serta lebih cepat mencapai viskositas puncak pada suhu tinggi (Berski et al. 2011).

Salah satu faktor penting yang mempengaruhi sifat fungsional pati modifikasi adalah jenis pati. Pati tapioka memiliki keunggulan dibandingkan dengan pati jenis lainnya seperti pada tingkat kelarutannya serta kemampuan mengembang yang lebih tinggi karena ukuran granula yang besar (Pomeranz 1991; Wurzburg 1989). Berdasarkan sifat tersebut, tapioka sesuai untuk dimodifikasi dengan proses metode ganda dengan penerapan hidroksipropilasi yang digabungkan dengan ikat silang. Penggunaan propilen oksida $12 \%$ dikombinasikan dengan STMP $3 \%$ : STPP 6\% dapat menghasilkan granula pati yang lebih berpori, dan merubah pola kristalinnya (Maulani et al. 2013). Maulani et al. (2019) menyatakan bahwa pati jagung putih yang dimodifikasi ganda dengan hidroksipropilasi digabungkan dengan ikat silang dapat mempercepat waktu gelatinisasi, kejernihan pasta, dan menurunkan sineresis sebesar $47.33 \%$ akan maksimal jika menggunakan rasio konsentrasi STMP: STPP sebesar 2\%:5\%. Oleh karena itu, kombinasi modifikasi tersebut dapat diterapkan pada pati tapioka.

Berdasarkan berbagai keunggulan dari pati termodifikasi ganda dengan hidroksipropilasi dan fosfat ikatsilang yang telah disampaikan, penelitian ini bertujuan untuk menghasilkan pati termodifikasi ganda yang memiliki karakteristik fisikomia yang sesuai kondisi pengolahan. Informasi tersebut dapat dijadikan sebagai dasar pengembangan ingredien bahan pangan yang dapat memperluas aplikasi penggunaan tapioka termodifikasi.

\section{BAHAN DAN METODE}

\section{Bahan}

Pada penelitian ini bahan yang digunakan adalah singkong kultivar UJ-5 dengan umur panen 10 bulan. Pati tapioka dimodifikasi dengan menggunakan bahan-bahan sebagai berikut propilena oksida (Sigma-Aldrich Chemical, USA), sodium tripolifosfat (STPP) dan sodium trimetafosfat (STMP) (Sigma-Aldrich Chemical, USA), $\mathrm{Na}_{2} \mathrm{SO}_{4}$ (Merck, Germany), $\mathrm{HCl}$ (Merck, Germany), $\mathrm{NaOH}$ (Merck, Germany), $\mathrm{H}_{2} \mathrm{SO}_{4}$ (Merck, Germany), natrium fosfat dihidroksi $\left(\mathrm{Na}_{2} \mathrm{H}_{2} \mathrm{PO}_{4}\right)$ (Merck, Germany), sedangkan pengujian kadar fosfat menggunakan reagen vanadat-molibdat (Merck, Germany).

Penelitian ini alat yang digunakan terdiri dari untuk pengujian kimia menggunakan spektrofotometer UV-Vis spectronic 20D+ (Hitachi U-2900, Jepang). Pengujian fisik menggunakan mikroskop polarisasi, Scanning Electron Microscope (SEM) (Hitachi TM3030, Jepang), Rapid Visco Analyzer (RVA) (Tecmaster, Australia) dan difraksi sinar-X (Miniflex 600 Nal scintillator, Rigoku Jepang). Peralatan lainnya adalah penggiling tepung, sentrifus, water bath, oven (H.ORTH 6700, German) $\mathrm{pH}$ meter, blender, refrigerator, freezer, termometer, neraca analitik, ayakan 100 mesh, penangas air, mikro pipet dan alat gelas lainnya.

\section{Ekstraksi pati singkong (modifikasi Lingga et al. 1986)}

Umbi singkong dikupas, dicuci dan dilakukan proses pemarutan dengan mesin pemarut. Air suhu ruang (20$25^{\circ} \mathrm{C}$ ) ditambahkan pada parutan singkong tersebut sebanyak 1:3.5, selanjutnya dilakukan proses penyaringan dengan menggunakan ayakan untuk menghasilkan suspensi pati singkong. Pengendapan suspensi pati singkong dilakukan sekitar tiga jam. Endapan pati yang sudah dihilangkan airnya, dilarutkan kembali dengan menambahkan air sebanyak 1:3.5 dan didiamkan sekitar 12 jam. Pada akhir proses pengendapan ini, air dipisahkan dan yang diambil adalah endapan pati singkongnya. Endapan pati singkong yang diperoleh, dikeringkan dengan menggunakan oven pada suhu $40^{\circ} \mathrm{C}$ sekitar selama 8 jam sam- 
pai diperoleh kadar air pati singkong hingga 12.0-14.0\% . Pati singkong yang sudah dikeringkan dengan oven, diayak dengan saringan ukuran 100 mesh. Sebagian pati hasil ekstraksi ini dianalisis sebagai pati kontrol.

\section{Modifikasi gabungan hidroksipropilasi dan ikat silang (Modifikasi Wattanacant et al. 2003; Aziz et al. 2004)}

Pati singkong sebanyak $100 \mathrm{~g}$ basis kering, dibuat suspensi $40 \%$ (b/v) dengan menggunakan natrium sulfat $10 \%$. Suspensi tersebut perlahan-lahan dihomogenkan dan nilai $\mathrm{pH}$-nya dinaikkan menjadi 10.5 dengan penambahan $\mathrm{NaOH}$ konsentrasi 5\%. Larutan propilena oksida 8, 10, dan $12 \%$ (v/b) ditambahkan kemudian dilakukan pengadukan secara perlahan sekitar 30 menit pada kondisi suhu ruang $\left(20-25^{\circ} \mathrm{C}\right)$. Setelah itu suspensi pati tersebut diletakkan pada inkubator goyang (suhu $40^{\circ} \mathrm{C} ; 200$ rpm) 24 jam. Kemudian suspensi pati singkong diberi campuran larutan STMP dan STPP dengan konsentrasi 2\%:5\% (b/b). Selanjutnya, pati tapioka perlahan-lahan dilakukan proses pengadukan kembali sekitar 30 menit pada suhu ruang $\left(20-25^{\circ} \mathrm{C}\right)$, ditambahkan $\mathrm{HCl}$ untuk menurunkan nilai $\mathrm{pH}$ sampai 5.5. Tahap selanjutnya adalah, penempatan kembali suspense pati singkong tersebut inkubator goyang pada suhu $40^{\circ} \mathrm{C}$ dengan kecepatan 200 rpm selama 24 jam. Suspensi pati singkong disentrifusi pada 2000xg selama 15 menit. Endapan kemudian dipisahkan sebagai pati singkong termodifikasi dan dilakukan proses pencucian dengan air secara berulang lima kali kemudian dilakukan pengeringan dengan oven menggunakan suhu $40^{\circ} \mathrm{C}$ sehingga diperoleh kadar air pati tapioka tersebut sekitar 10.0-12.0\%. Tahap akhir dari modifikasi ini adalah pati diayak dengan ukuran 100 mesh.

\section{Penetapan rendemen pati singkong dan sifat fisiko- kimia pati}

Rendemen pati singkong dilakukan dengan membandingan berat pati hasil ekstraksi dengan berat umbi singkong. Penentuan sifat kimia pati terdiri dari kadar air (AOAC 2012), kadar fosfor dengan menggunakan spektrofotometer (metode Vanadat-Molibdat, AOAC 2012). Untuk penetapan sifat fisik terdiri dari analisis profil gelatinisasi menggunakan RVA, morfologi granula pati, kejernihan pasta, swelling power dan difraksi sinar-X.

\section{Analisis profil gelatinisasi pati (RVA Standar 2)}

Sampel ditimbang sebanyak $3 \mathrm{~g}$ sampel basis kering dan dimasukkan ke dalam pan RVA, ditambahkan sebanyak $25 \mathrm{~g}$ air destilata. Pati singkong yang sudah diberi air, dipanaskan suhu $50^{\circ} \mathrm{C}$ sampai mencapai suhu $95^{\circ} \mathrm{C}$, kecepatan yang digunakan $6^{\circ} \mathrm{C} /$ menit, kemudian holding selama lima menit. Dilanjutkan dengan fase pendinginan, pada kondisi ini, penurunan suhu dilakukan dari suhu $95^{\circ} \mathrm{C}$ sampai $50^{\circ} \mathrm{C}$, dengan pengaturan kecepatan yaitu $6^{\circ} \mathrm{C} /$ menit, holding selama dua menit. Hasil pengujian dengan RVA adalah diperolehnya data suhu awal gelatinisasi, viskositas puncak, viskositas pada suhu $95^{\circ} \mathrm{C}$, viskositas breakdown, viskositas setelah mencapai suhu $50^{\circ} \mathrm{C}$, viskositas akhir setelah dipertahankan di suhu $50^{\circ} \mathrm{C}$, viskositas setback dan kestabilan pengadukan pada suhu $50^{\circ} \mathrm{C}$.

\section{Analisis morfologi granula (Srichuwong 2006)}

Ukuran granula pati $(\mu \mathrm{m})$ diamati dengan mikroskop polarisasi cahaya pada persebaran 200x. Preparasi sampel dilakukan dengan cara mengambil sebanyak satu sudip sampel pati kemudian dilarutkan dalam $\pm 20 \mathrm{~mL}$ air. Kemudian larutkan diteteskan keatas gelas objek dan ditutup. Setelah itu diamati menggunakan mikroskop dan hasilnya dicetak pada film. Preparasi sampel yang dilakukan sebelum analisis morofologi dengan SEM adalah dengan meletakkan serbuk pati pada wadah sample dengan isolasi double-side yang kemudian dilapisi dengan emas dan dimasukkan ke dalam SEM. Instrumen Scanning Electron Microscope (SEM) (JOEL JSM6510LA, USA) digunakan untuk mempelajari morfologi granula pati tapioka sebelum dan sesudah dimodifikasi dengan menggunakan skala pembesaran 500 dan 800 kali dan hasil pengamatan difoto dengan kamera digital.

\section{Penentuan kadar fosfor (Vanadat-Molibdat, AOAC 2012)}

Pati tapioka termodifikasi ditimbang sebanyak 2-3 g ke dalam cawan, kemudian dimasukkan ke dalam tanur listrik suhu $550^{\circ} \mathrm{C}$ selama 12 jam untuk diabukan. Setelah menjadi abu, sampel ditambahkan $\mathrm{HCl}$ encer sebanyak 40-50 mL (1+1) secara bertahap. Setelah itu dipanaskan selama 60 menit, kemudian ditambahkan kembali $10 \mathrm{~mL}$ $\mathrm{HCl}$ encer (1+1) dan disaring dengan kertas saring yang ditampung dalam labu takar $100 \mathrm{~mL}$. Setelah itu ditepatkan dengan akuades.

Larutan vanadat-molibdat dibuat dengan cara melarutkan $20 \mathrm{~g}$ ammonium molibdat pada akuades suhu $50^{\circ} \mathrm{C}$ sebanyak $400 \mathrm{~mL}$ kemudian didinginkan hingga suhu ruang. Setelah itu pada gelas piala yang lain melarutkan $1 \mathrm{~g}$ ammonium vanadat dalam $300 \mathrm{~mL}$ air suhu $100^{\circ} \mathrm{C}$ kemudian didinginkan dan ditambahkan $\mathrm{HCl}$ pekat $140 \mathrm{~mL}$ dan diaduk secara perlahan. Larutan molibdat yang telah jadi dicampur dengan larutan vanadate dan diaduk kemudian diencerkan dengan akuades sampai $1 \mathrm{~L}$.

Preparasi sampel dilakukan dengan mengambil $5 \mathrm{~mL}$ larutan abu ke dalam labu takar $50 \mathrm{~mL}$ kemudian ditambahkan $20 \mathrm{~mL}$ akuades dan $1.25 \mathrm{~mL}$ pereaksi vanadat molibdat, setelah itu diencerkan dengan akuades hingga tanda tera, didiamkan 10 menit. Setelah itu dikur absorbansi dengan spektrofotometer panjang gelombang 400 nm. Kadar fosfor pada sampel dihitung dengan persamaan sebagai berikut:
Kadar $\mathrm{P}_{2} \mathrm{O}_{5}(\%)=[($ Absorbansi-b $\mathrm{x} \mathrm{V}$ x larutan abu $\mathrm{x}$ $0.1) / \mathrm{a}] / \mathrm{W}$

Kadar $\mathrm{P}(\%)=\left(\right.$ Kadar $\left.\mathrm{P}_{2} \mathrm{O}_{5} \times \mathrm{BM} \mathrm{P}\right) / \mathrm{BM} \mathrm{P}_{2} \mathrm{O}_{5}$

dimana, $\mathrm{a}=$ slope kurva kalibrasi, $\mathrm{b}=$ intercept kurva kalibrasi, $\mathrm{W}=$ berat sampel pada saat pengabuan $(\mathrm{g})$ 


\section{Derajat substitusi (Matos dan Perez 2003)}

Derajat substitusi dihitung berdasarkan persamaan yaitu: $\mathrm{S}=162 \mathrm{x}$ kadar P basis kering (\%)/ [3100-(102 x kadar $\mathrm{P}$ basis kering)].

\section{Kejernihan pasta (Maulani et al. 2013)}

Larutan pati singkong $1 \%$ dipanaskan dan diaduk dalam water bath suhu $95^{\circ} \mathrm{C}$ sekitar 30 menit, dilanjutkan dengan proses pendinganan hingga suhu $25^{\circ} \mathrm{C}$ selama satu jam. Kejernihan pasta pati singkong dilihat dari persen transmitan pada panjang gelombang $650 \mathrm{~nm}$ dengan spektrofotometer. Persen transmitan (\%T) ditetapkan sebagai parameter pengujian dengan air destilata sebagai blanko.

\section{Penetapan kristanilitas pati dengan difraksi sinar-X (Zobel 1988)}

Difraksi sinar-X (difraktometer merk Philips Shimadzu, Jepang monokromatik dengan radiasi kobalt, 31 $\mathrm{kV}, 26 \mathrm{~mA}$ ), 4 detik dengan kecepatan kertas adalah dari $1 \mathrm{~cm} /$ menit. Hasil pengujian ini berupa difraktogram berupa $2 \theta$ dari 4 sampai $30^{\circ}$ yang dihasilkan dengan kecepatan scan adalah $1 \%$ menit.

\section{HASIL DAN PEMBAHASAN}

\section{Rendemen pati singkong}

Proses ekstraksi pati singkong menghasilkan rendemen pati $25.49 \%$ dengan kadar air $12.47 \%$. Hasil penelitian Susilawati et al. (2008) menyatakan bahwa rendemen pati meningkat dengan bertambahnya umur panen hingga 10 bulan dengan kadarnya sebesar $18.94 \%$. Hasil penelitian yang diperoleh lebih tinggi dibandingkan dengan literatur dikarenakan sifat fisik dan kimia pati sangat dipengaruhi oleh faktor genetik serta kondisi tempat tumbuh (Moorthy 2002).

\section{Kadar fosfor dan derajat subtitusi}

Pati tapioka termodifikasi mengandung fosfor dalam kisaran 0.032-0.076\% lebih tinggi bila dibandingkan dengan kontrol (0.029\%) (Tabel 1). Lim dan Seib (1993) melaporkan bahwa berdasarkan regulasi pemerintah Amerika Serikat kadar fosfor maksimum yang diperbolehkan dalam modifikasi pati komersial adalah $0.40 \%$. Hasil penelitian ini larutan propilena oksida $8-12 \%$ yang dikombinasikan dengan campuran 2\% STMP: 5\% STPP memiliki kadar fosfor $<0.4 \%$. Penetapan kadar fosfor dapat digunakan untuk memperlihatkan terbentuknya jembatan fosfor pada molekul pati.

Nilai derajat substitusi (DS) yang paling tinggi adalah pati tapioka modifikasi gabungan perlakuan propilen oksida $10 \%$ dengan 2\% STMP:5\% STPP sebesar 0.004 \pm $0.000 \%$ dengan kadar fosfor paling tinggi dalam penelitian ini yaitu $0.076 \pm 0.001 \%$. Nilai DS yang dihasilkan pada modifikasi pati singkong lebih kecil dibandingkan dengan nilai DS pada modifikasi ganda pati garut hidroksipropilasi-ikat silang dengan kisaran sebesar 0.037$0.261 \%$, akan tetapi nilai tersebut masih dalam kisaran yang diperbolehkan oleh Food and Drug Administration (FDA), yaitu maksimal 7\% (Maulani et al. 2013; Woggum et al. 2014). Derajat subtitusi (\% grup hidroksil) menunjukkan persentase subsitusi gugus hidroksi oleh gugus hidroksipropil pada rantai amilosa dan kadar fosfor dalam granula tersebut (Maulani et al. 2013). Salah satu fator yang memengaruhi nilai derajat subtitusi adalah jenis pati yang dimodifikasi. Pati dengan kadar amilopektin lebih tinggi memiliki kandungan fosfor lebih banyak sehingga menghasilkan nilai DS yang lebih besar (Passauer et al. 2010).

Tabel 1. Kandungan fosfor dan derajat subtitusi pati tapioka kontrol dan termodifikasi

\begin{tabular}{lcc}
\hline \multicolumn{1}{c}{ Perlakuan } & $\% \mathbf{P}^{*}$ & DS $^{*}$ \\
\hline Kontrol & $0.029 \pm 0.000$ & - \\
P $8 \%+($ STMP:STTP) & $0.032 \pm 0.001$ & $0.001 \pm 0.000$ \\
P $10 \%+$ (STMP:STTP) & $0.076 \pm 0.001$ & $0.004 \pm 0.000$ \\
P $12 \%+$ (STMP:STTP) & $0.044 \pm 0.000$ & $0.002 \pm 0.000$ \\
\hline
\end{tabular}

Keterangan: Hasil merupakan standar deviasi dari 3 ulangan. $P$ (propilen oksida); DS= Dejarat substitusi

\section{Kadar air dan pH}

Pada Tabel 2, kadar air pada pati tapioka termodifikasi antara 7.82-8.19\% dan nilai $\mathrm{pH}$ pati termodifikasi berada pada kisaran 7.04-7.26. Nilai kadar air pati termodifikasi ganda lebih rendah dibandingkan dengan nilai kadar air pati singkong termodifikasi biologi selama 72 jam yaitu sebesar $9.44 \%$. Nilai $\mathrm{pH}$ pati singkong modifikasi ganda lebih tinggi dibandingkan pati singkong termodifikasi biologi sebesar 3.85-8.02 (Kartikasari et al. 2016).

Proses modifikasi pada pati tapioka menyebabkan adanya perubahan $\mathrm{pH}$ pati tapioka alami yang cenderung asam dari pH 5.6 menjadi pH netral cenderung naik menjadi $\mathrm{pH}$ basa pada pati termodifikasi. Hal ini disebabkan adanya penambahan $\mathrm{NaOH}$ sampai $\mathrm{pH} 10.5$ pada proses modifikasi ganda sebelum ditambahkan propilen oksida. $\mathrm{pH}$ yang tinggi dibutuhkan dalam proses hidroksipropilasi menggunakan propilen oksida karena akan memicu reaksi nukleofilik pada alkoxy anion yang akan menyerang gugus epoksi propilen oksida. Hal ini menyebabkan adanya konversi pada grup hidroksil polisakarida pati menjadi gugus alkoksida (Fu et al. 2018).

Tabel 2. Kadar air dan nilai $\mathrm{pH}$ pati tapioka kontrol dan termodifikasi

\begin{tabular}{lcc}
\hline \multicolumn{1}{c}{ Perlakuan } & Kadar Air $(\% \mathbf{b b})$ & pH \\
\hline Kontrol & 12.47 & 5.60 \\
P 8\% + (STMP:STTP) & 7.82 & 7.04 \\
P 10\% + (STMP:STTP) & 7.78 & 7.21 \\
P 12\% + (STMP:STTP) & 8.19 & 7.26 \\
\hline
\end{tabular}

Keterangan: P (propilen oksida); STMP: (sodium tri meta fosfat); STPP: (sodium tri poli fosfat)

\section{Bentuk granula pati}

Granula pati tapioka kontrol maupun yang sudah termodifikasi masih memiliki sifat birefringence-nya, yang dapat dilihat pada Gambar 1. Pati tapioka hasil penelitian ini, memiliki bentuk granula pati yang relatif seragam, yaitu bulat dan oval (Gambar 1, A-D). 
Granula pati yang diamati pada mikroskop menunjukkan pola maltose cross atau dikenal dengan sifat birefringence. Hal tersebut dapat dilihat dari bias indeks refraksi granula pati yang berwarna biru-kuning yang dipengaruhi oleh struktur molekul amilosa yang terdapat di dalam pati (French 1984; Taggart 2004). Apabila pati mengalami proses pemanasan dan tergelatinisasi, maka sifat birefringence akan hilang. Berdasarkan pengamatan dibawah mikroskop, dapat dilihat bahwa pola maltose cross pati tapioka hasil penelitian masih nampak utuh.

Berdasarkan hasil pengamatan menggunakan Scanning Electron Microscopy (SEM), granula pati tapioka pada penelitian ini terlihat tidak ada perubahan antara pati tapioka kontrol dengan termodifikasi. Proses modifikasi yang dilakukan tidak merubah bentuk granula pati (Gambar 1, E-H).

\section{Profil gelatinisasi pati tapioka kontrol dan termo- difikasi}

Hasil penelitian dengan menggunakan RVA, profil gelatinisasi tapioka dapat dilihat pada Gambar 2 sedangkan datanya disajikan pada Tabel 3. Menurut Chen (2003), pola gelatinisasi menunjukkan perubahan viskositas pati selama proses pengolahan pada suhu tinggi dan pada saat suhu diturunkan. Hal ini dapat digunakan sebagai salah satu cara untuk memprediksi bagaimana karakteristik fungsional pati dan aplikasi pati tersebut di dalam produk pangan secara optimal (Chen 2003).

Profil gelatinisasi pada pati tapioka adalah tipe A dengan ciri puncak pasta yang cukup tinggi (peningkatan viskositas) dan kemudian viskositasnya menurun dengan cepat selama proses pemanasan. Jenis pati ini cenderung tidak tahan proses pemanasan dan pengadukan. Modifikasi ganda pada pati tapioka ini menyebabkan peningkatan viskositas dan penurunan suhu gelatinisasi apabila dibandingkan dengan pati tapioka kontrol.

Gambar 2 menunjukkan bahwa gabungan modifikasi antara ikat silang dengan fosforilasi menyebabkan viskositas pati meningkat karena adanya reaksi jenis ikat silang antara rantai pati yang dapat mempertahankan kondisi granula dari kerusakan selama proses pemanasan dan reaksi fosforilasi dapat menurunkan kecepatan kerusakan tersebut (Deetae et al. 2008). Tabel 3 menunjukkan bahwa pada $\mathrm{pH}$ netral, modifikasi ganda pati tapioka ini sedikit menurunkan suhu gelatinisasi $\left(<68^{\circ} \mathrm{C}\right)$ dibandingkan pati tapioka alami $\left(68.5^{\circ} \mathrm{C}\right)$. Hasil penelitian Maulani et al. (2019) menunjukkan modifikasi ganda hidroksipropilasi-ikat silang pada pati jagung putih dapat mengurangi suhu gelatinisasi dari $73.25^{\circ} \mathrm{C}$ (pati kontrol) menjadi $68.85^{\circ} \mathrm{C}$ (pati modifikasi). Pati tapioka hasil modifikasi gabungan ini, mempunyai viskositas breakdown yang lebih rendah yaitu 698-1530 cP dibandingkan dengan tapioka kontrol $(4089 \mathrm{cP})$. Modifikasi ganda pati tapioka ini menyebabkan perubahan pada puncak viskositas yang lebih tinggi dan stabil terhadap terhadap pemanasan dan tidak terpengaruh oleh proses pengadukan. Semakin rendah nilai viskositas breakdown, maka pati semakin tahan proses pemanasan, pasta pati tidak cepat mengalami pengenceran, sehingga pati dapat dijadikan sebagai bahan pengental.

Tabel 3. Profil gelatinisasi pati tapioka kontrol dan termodifikasi

\begin{tabular}{|c|c|c|c|c|}
\hline \multirow{2}{*}{ Parameter } & \multicolumn{4}{|c|}{ pH Netral } \\
\hline & Kontrol & P 8\% & P $10 \%$ & P 12\% \\
\hline $\begin{array}{l}\text { Waktu gelatinisasi } \\
\text { (menit) }\end{array}$ & 5.93 & 8.33 & 7.33 & 7.27 \\
\hline $\begin{array}{l}\text { Suhu awal } \\
\text { gelatinisasi }\left({ }^{\circ} \mathrm{C}\right)\end{array}$ & 68.5 & 67.3 & 66.65 & 65.2 \\
\hline $\begin{array}{l}\text { Viskositas Puncak } \\
\text { (cP) }\end{array}$ & 5635 & 5735 & 5317 & 6593 \\
\hline $\begin{array}{l}\text { Viskositas akhir } \\
\text { setelah holding } \\
\text { pada suhu } 95^{\circ} \mathrm{C} \\
\text { (cP) }\end{array}$ & 1546 & 4979 & 4619 & 5063 \\
\hline $\begin{array}{l}\text { Viskositas } \\
\text { Breakdown (cP) }\end{array}$ & 4089 & 756 & 698 & 1530 \\
\hline $\begin{array}{l}\text { Viskositas akhir } \\
\text { setelah holding } \\
\text { pada suhu } 50 \mathrm{C}(\mathrm{cP})\end{array}$ & 2738 & 8178 & 8183 & 8199 \\
\hline $\begin{array}{l}\text { Viskositas Setback } \\
\text { (cP) }\end{array}$ & 1192 & 3199 & 3564 & 3136 \\
\hline
\end{tabular}

Keterangan: $\mathrm{P}$ (propilen oksida); STMP: (sodium tri meta fosfat); STPP: (sodium tri poli fosfat)
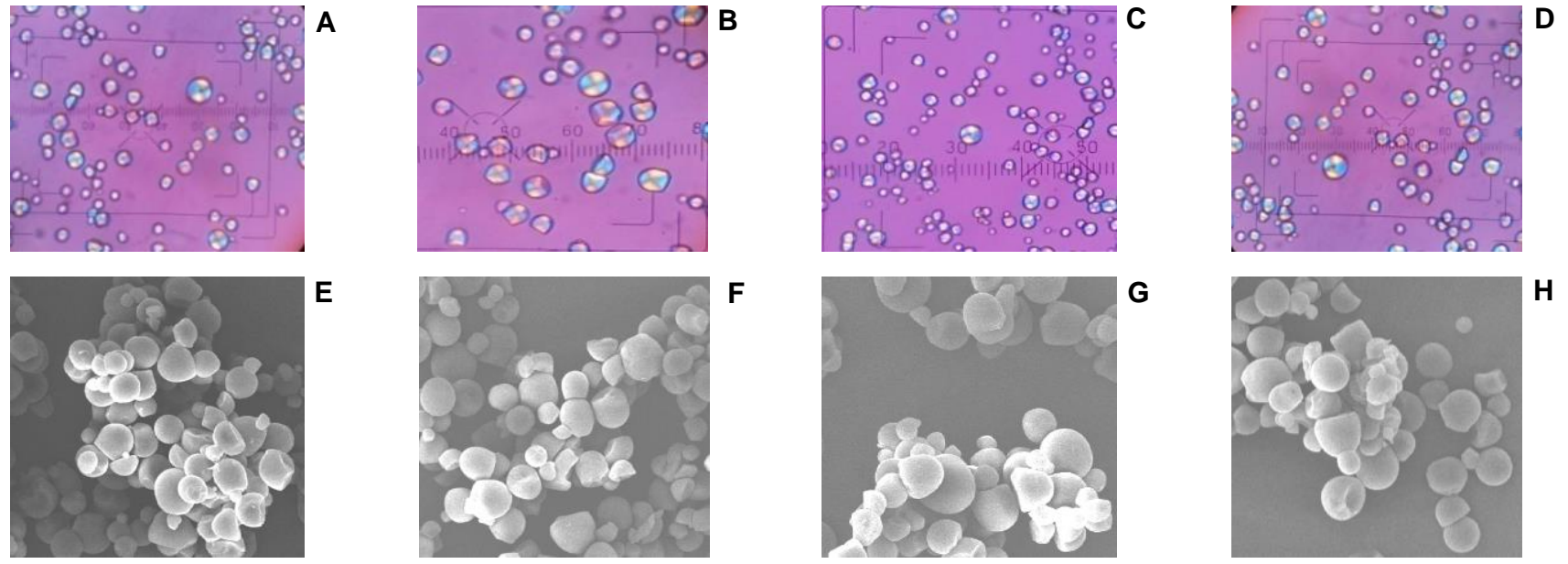

Gambar 1. Granula pati tapioka di bawah mikroskop polarisasi (perbesaran 400x, 1 skala:10 $\mu$ m) dan SEM. Mikroskop polarisasi: (a) kontrol; (b) P 8\% + (STMP:STTP); (c) P 10\% + (STMP:STTP); (d) P 12\% + (STMP:STTP) SEM (750x); (e) control; (f) P 8\% (STMP:STTP); (g) P 10\% + (STMP:STTP); (h) P 12\% + (STMP:STTP) 


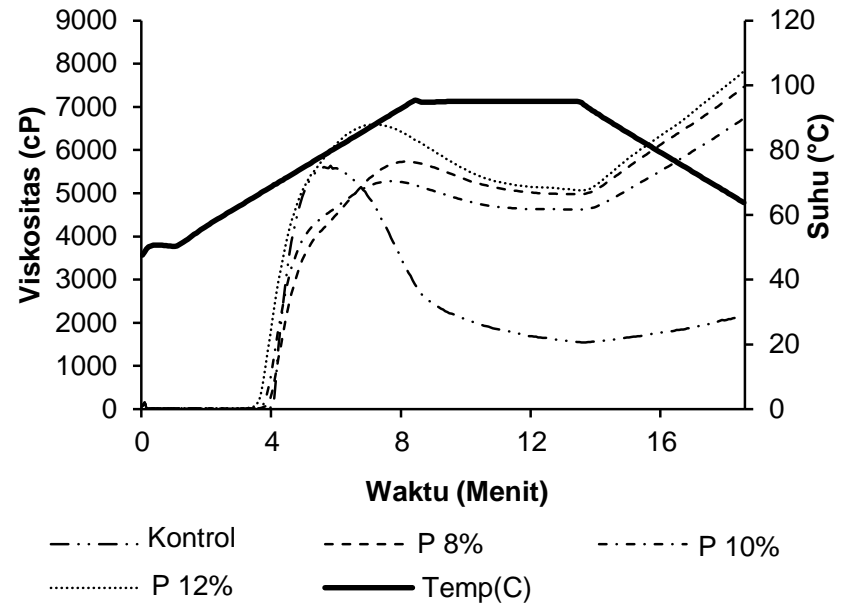

Gambar 2. Profil gelatinisasi pati tapioka kontrol dan termodifikasi menggunakan RVA

Tabel 3 menunjukkan bahwa viskositas setback pati termodifikasi mempunyaii nilai yang lebih tinggi (3136$3564 \mathrm{cP})$ dibanding pati tapioka kontrol (1192 cP), yang ditandai dengan viskositas akhir yang tinggi.

\section{Kejernihan pasta}

Tabel 4 menunjukkan adanya penurunan nilai kejernihan pasta pada pati termodifikasi ganda $(\% \mathrm{~T}$ pada $\lambda 650$ $\mathrm{nm})$. Terlihat bahwa peningkatan konsentrasi propilen oksida, dapat menurunkan nilai kejernihan pasta. Hal ini juga terjadi pada hasil penelitian Wattanacant et al. (2003), pasta pati sagu termodifikasi mengalami penurunan kejernihan pasta sejalan dengan hasil penelitian ini.

Metode pengujian kejernihan pasta, pati dipanaskan sampai $95^{\circ} \mathrm{C}$ kemudian suhu diturunkan sampai mencapai $25^{\circ} \mathrm{C}$. Pemanasan pada sampel pati tapioka kontrol menyebabkan terjadinya proses gelatinisasi dan ditandai dengan pasta yang jernih sebesar $46.35 \pm 0.494 \%$. Pasta pati tapioka yang mengalami modifikasi ganda memiliki nilai kejernihan pasta yang lebih rendah (10.30-17.55\%) dengan nilai terendah pada pati konsentrasi propilen oksida $12 \%$ yaitu sebesar $10.30 \pm 0.282 \%$. Peningkatan konsentrasi propilen oksida menyebabkan penurunan nilai kejernihan pasta pati. Modifikasi ganda ini dapat menyebabkan terbentuknya ikatan kovalen karena adanya ikat silang pada pati sehingga menyebabkan kesulitan dalam mengabsopsi air. Hal ini yang mengakibatkan proses gelatinisasi pati tidak sempurna dan terjadi penurunan kejernihan pasta (Shen et al. 2019).

Tabel 4. Pengaruh konsentrasi propilena oksida dan campuran STMP:STPP terhadap kejernihan pasta pati tapioka hasil modifikasi hidroksipropilasi dan ikat silang

\begin{tabular}{lc}
\hline \multicolumn{1}{c}{ Perlakuan } & Kejernihan Pasta $\left(\% \mathbf{T}_{\text {} 650}\right)$ \\
\hline Kontrol & $46.35 \pm 0.494$ \\
P $8 \%+($ STMP:STTP) & $17.55 \pm 0.070$ \\
P $10 \%+($ STMP:STTP) & $12.25 \pm 0.212$ \\
P $12 \%+($ STMP:STTP) & $10.30 \pm 0.282$ \\
\hline
\end{tabular}

Keterangan: Hasil merupakan standar deviasi dari 3 ulangan. Keterangan: P (propilen oksida); STMP: (sodium tri meta fosfat); STPP: (sodium tri poli fosfat)

\section{Derajat kristalinitas dan pola difraksi sinar-X}

Pengujian dengan menggunakan difraksi sinar- $X$ memperlihatkan bahwa pati tapioka termasuk ke dalam pola kristalin Tipe A yang tidak mengalami perubahan setelah pati mengalami modifikasi (Gambar 3). Derajat kristalinitas pati tapioka kontrol $(29.47 \%)$ dan termodifikasi sebesar 24.79-29.64\%. Faridah (2011), penurunan derajat kristalinitas tersebut menggambarkan area daerah kristalin semakin berkurang. Berkurangnya area kristalin tersebut dikarenaka proses modifikasi dengan propilen oksida dan STTP dan STMP selama 48 jam dapat menyebabkan terjadi perubahan pada struktur kristalin granula pati tapioka termodifikasi tersebut (Tabel 5).

Tabel 5. Derajat kristalinitas pati tapioka kontrol dan termodifikasi

\begin{tabular}{lcc}
\hline \multicolumn{1}{c}{ Perlakuan } & $\begin{array}{c}\text { Tipe } \\
\text { Kristalin }\end{array}$ & Derajat Kristalinitas (\%) \\
\hline Kontrol & A & 29.47 \\
P 8\% + & A & 24.79 \\
(STMP:STTP) & & \\
P 10\%+ + & A & 25.73 \\
(STMP:STTP) & & 29.64 \\
P 12\%+ & A & \\
(STMP:STTP) & & \\
\hline
\end{tabular}



Gambar 3. Hasil difraksi sinar-X pati tapioka kontrol dan termodifikasi. P 8\% + (STMP:STTP); P 10\% + (STMP:STTP); P 12\% + (STMP:STTP)

Tabel 6. Perlakuan terbaik karakteristik sifat fisik dan kimia pati berdasarkan penambahan propilen oksida

\begin{tabular}{ll}
\hline \multicolumn{1}{c}{ Parameter } & \multicolumn{1}{c}{ Hasil } \\
\hline Kadar fosfor dan & Kadar fosfor tertinggi diperoleh pada \\
derajat substitusi & konsentrasi PO 10\% sebesar 0.076\% \\
dengan derajat substitusi sebesar & 0.004. Kemudian ketika konsentrasi PO \\
& meningkat menjadi 12\%, kadar fosfor \\
dan nilai DS berkurang & Kadar air terendah didapatkan pada \\
& konsentrasi PO sebesar 10\% yaitu \\
Kadar air & $7.78 \%$ \\
& Nilai pH tertinggi didapatkan pada saat \\
konsentrasi PO yang ditambahkan \\
Nilai pH & sebesar 12\% yaitu 7.26 \\
& Nilai viskositas breakdown pada pH \\
Viskositas & netral terendah didapatkan pada \\
breakdown & penambahan PO 10\% sebesar 698 cP \\
Viskositas seatback & Nilai viskositas seatback pada pH netral \\
& tertinggi didapatkan pada penambahan \\
& PO 10\% sebesar 3564 cP \\
Kejernihan pasta & Tingkat kejernihan pasta terendah \\
& didapatkan pada saat penambahan PO \\
& 12\% yaitu sebesar 10.3\% \\
\hline
\end{tabular}


Berdasarkan beberapa sifat fisik dan kimia pati, masing-masing konsententrasi propilen oksida yang ditambahkan memiliki karakteristik pati sebagai berikut (Tabel 6). Dapat disimpulkan bahwa pati singkong yang dimodifikasi ganda dengan penambahan propilen oksida sebesar 10\% dengan campuran STMP : STTP (2\%:5\%) memiliki karakteristik sifat fisik dan kimia yang terpilih.

\section{KESIMPULAN}

Modifikasi gabungan antara hidrosipropilasi dengan taut silang pada pati tapioka dapat merubah karakteristik fisiknya yaitu dapat meningkatkan kadar fosfor sehingga dapat meningkatkan nilai derajat substitusinya (DS), tidak menyebabkan perubahan pada morfologi granula pati dan tipe kristalinnya (tipe A) serta masih memiliki sifat birefringencenya. Selain itu, modifikasi pati taioka ini dapat menurunkan persen kejernihan pasta, suhu gelatinisasi pati, nilai viskositas breakdown dan meningkatkan viskositas puncak, viskositas pada $95^{\circ} \mathrm{C}$, serta viskositas akhir. Pati tapioka hasil modifikasi gabungan antara propilen oksida konsentrasi 10.00 dan $12.00 \%$ dengan campuran STMP:STTP (2\%:5\%) memiliki memiliki karakteristik ketahanan terhadap panas dan pengadukan lebih baik dibandingkan dengan pati tapioka kontrol.

\section{UCAPAN TERIMA KASIH}

Terima kasih kepada PT Indofood Sukses Makmur Tbk yang telah membiayai penelitian ini melalui Program Indofood Riset Nugraha (IRN).

\section{DAFTAR PUSTAKA}

Atichokudomchai N, Shobsngob S, Varavinit S. 2000. Morphological properties of acid modified tapioka starch. Starch/Starke 52(8-9):283-289. DOI: 10.10 02/1521-379X(20009)52:8/9<283::AIDSTAR283> 3.0.CO;2-Q.

Aziz A, Daik R, Ghani MA, Daud NIN, Yamin BM. 2004. Hydroxypropylation and acetylation of sago starch. Malays J Chem 6: 048-054.

Beninca C, Demiate IM, Lacerda LG, Carvalho Filho MAS, Ionashiro M, Schnitzler E. 2008. Thermal behavior of corn starch granules modified by acid treatment at 30 and $50^{\circ} \mathrm{C}$. Eclet. Quim 33(3): 13-18. DOI: $10.1590 / \mathrm{S} 0100-46702008000300002$.

Berski W, Ptaszek A, Ptaszek P, Ziobro R, Kowalski G, Grzesik M, Achremowicz B. 2011. Pasting and rheological properties of oat starch and its derivatives. Carbohyd Polym 83(2): 665- 671. DOI: 10.1016/j.carbpol.2010.08.036.
Chen Z. 2003. Physicochemical Properties of Sweet Potato Starches and Theirapplication in Noodle Products. [Tesis]. Wageningen (Belanda), Wageningen University.

Deetae P, Shobsngob S, Varanyanond W, Chinachoti P, Naivikul O, Varavinit S. 2008. Preparation, pasting properties and freeze-thaw stability of dual modified crosslink-phosphorylated rice starch. Carbohyd Polym 73: 351-358. DOI: 10.1016/j.carbpol.2007. 12.004.

Faridah DN . 2011. Perubahan Karakteristik Kristalin Pati Garut (Marantha arundinaceae L.) dalam Pengembangan Pati Resisten Tipe III. [Disertasi]. Bogor: Sekolah Pascasarjana, Institut Pertanian Bogor.

French D. 1984. Organization of Starch Granules. Di dalam Whistler RL, BeMiller JN, Paschall EF, editor. Starch : Chemistry and Technology. New York (US), Academic Press, Inc.

Fu Z, Zhang L, Ren M-H, BeMiller JN. 2018. Developments in hydroxypropilation of starch: a review. Starch-Starke 71(1-2). DOI: 10.1002/star.20180 0167.

Greenwood CT, Muir DD, Whitcher HW. 1977. Hydroxyethyl starch as a cryoprotective agent for human red blood cells the relation between the molecular properties and the cryoprotective effect. StarchStaerke 29: 343-349. DOI: 10.1002/star.1977 0291005.

Haq F, Yu H, Wang L, Teng L, Haroon M, Khan RU, Mehmood S, Ul Amin B, Ullah RS, Khan A, Nazir A. 2019. Advances in chemical modifications of starches and their applications. Carbohy Res 476: 1235. DOI: 10.1016/j.carres. 2019.02.007.

Hirsch JB, Kokini JL. 2002. Understanding the mechanism of crosslinking agents ( $\mathrm{POCl}_{3}, \mathrm{STMP}$, and EPI) through swelling behavior and pasting properties of cross-linked waxy maize starches. Cereal Chem 79: 102-107. DOI: 10.1094/CCHEM. 2002.79.1.102.

Kartikasari SN, Sari P, Subagio M. 2016. Karakterisasi sifat kimia, profil amilogravi (RVA) dan morofologi granula (SEM) pati singkong termodifikasi secara biologi. J Agroteknologi 10(1): 12-24.

Lim S, Seib PA. 1993. Preparation and pasting properties of wheat and waxy corn starch phosphates. Cereal Chem 70: 137-144.

Lingga PB, Sarwono F, Rahadi PC, Raharja JJ, Afistini, Rini W, Apriadi WH. 1986. Bertanam Umbi-umbian. Jakarta (ID), Penebar Swadaya.

Matos ME, Pérez E. 2003. Characterization of native and modified cassava starches I. Ultrastructural study by scanning electron microscopy and X-ray diffraction techniques. Cereal Food World 48: 78-81. 
Maulani RR, Fardiaz D, Kusnandar F, Sunarti TC. 2013 Characterization of chemical and physical properties of hydroxypropylated and cross-linked arrowroot (Marantha arundinacea) starch. Int J Eng 45(3): 207221. DOI: 10.5614/j.eng.technol.sci.2013.45.3.1.

Maulani RR, Hidayat A, Husyari UD. 2019. Functional properties of dual modified white corn starch. Int J Recent Technol Eng 7(6S5): 1624-1628.

Moin A, Ali MT, Hasnain A. 2017. Characterization and utilization of hydroxypropylated rice starches for improving textural and storage properties of rice puddings. Int J Biol Macromol 105(1): 843-851. DOI: 10.1016/j.ijbiomac.2017.07.109.

Moorthy SN. 2002. Physicochemical and functional properties of tropical tuber starches: A review. Starch/Stärke 54: 559-592. DOI: 10.1002/1521379X(200212)54:12<559::AID-STAR2222559>3.0. $\mathrm{CO} ; 2-\mathrm{F}$.

Neelam K, Vijay S, Lalit S. 2012. Various techniques for the modification of starch and the applications of its derivates. Int Res J Pharm 3(5): 25-31.

Passauer L, Bender H, Fischer S. 2010. Synthesis and characterization of starch phospates. Carbohyd Polym 82: 809-814. DOI: 10.1016/j.carbpol.2010. 05.050 .

Pomeranz Y. 1991. Functional Properties of food Components (2nded). New York, Academic Press, Inc.

Senanayake S, Gunaratne A, Ranaweera KKDS, Bamunuarachchi A. 2014. Effect of hydroxypropy-lation on functional properties of different cultivars of sweet potato starch in Sri Lanka. Int J Food Sci 2014: 148982. DOI: 10.1155/2014/148982.

Shen Y, Zhang N, Xu Y, Huang J, Yuan M, Wu D. 2019. Physicochemical properties of hydroxypropylated and cross-linked rice starches differential in amylose content. Macromeleculers 128: 775-781. DOI: 10.10 16/j.ijbiomac.2019.01.194.
Srichuwong S. 2006. Starch from Different Plant Origins: from Structure to Physicochemical Properties [Disertasi]. Jepang: Tsu Mie University.

Susilawati, Nurdjanah S, Putri S. 2008. Karakteristik sifat fisik dan kimia ubi kayu (Manihot esculenta) berdasarkan lokasi penanaman dan umur panen berbeda. J Tek Ind Hasil Pert 13(2): 59-72.

Taggart P. 2004. Starch as an ingredient: manufacture and applications. Eliasson AC, editor. Starch in food. Struc-ture, function, and application. Cambridge (GB), Woodhead Publishing: 363-392. DOI: 10.15 33/9781855739093.3.363

Wattanacant S, Muhammad SKS, Hasyim DM, Rahman RA. 2002. Characterization of hydroxypropylated crosslinked sago starch as compared to commercial modified starches. Songklanakarin J Sci Technol 24(3): 439-450.

Wattanachant S, Muhammad K, Hashim DM, Rahman RA. 2003. Effect of crosslinking reagents and hydroxylpropylation levels on dual-modified sago starch properties. J Food Chem 80:463-471. DOI: 10.1016/ S0308-8146(02)00314-X.

Woggum T, Sirivongpaisal P, Wittaya T. 2014. Properties and characteristics of dual-modified rice starch based biodegradable films. Int J Biol Macromol 67: 490502. DOI: 10.1016/j.ijbiomac.2014.03.029.

Wurzburg OB. 1989. Modified Starches: Properties and Uses, 4th Printing, Boca Raton (FL), CRC Press.

Zobel H. 1988. Molecules to granules: A compressive starch review. Starch/Starke 40: 44-50. DOI: 10. 1002/star.19880400203.

JMP-04-20-07-Naskah diterima untuk ditelaah pada 01 Maret 2020. Revis makalah disetujui untuk dipublikasi pada 15 April 2020. Versi Online: http://journal.ipb.ac.id/index.php/jmpi 